\title{
Pengaruh Kepemimpinan, Lingkungan Kerja Terhadap Semangat Kerja Yang Berdampak Pada Kinerja Pegawai Dinas Sosial Kota Palembang
}

\author{
Dwi Ariestianah, Zunaidah \& Omar Hendro \\ Program Pascasarjana Magister Manajemen Universitas Muhammadiyah Palembang \\ Email: ariestianah87@.gmail.com
}

\begin{abstract}
This study aims to determine the effect of leadership, work environment on morale which has an impact on the performance of the Palembang City Social Service staff. The research approach is quantitative research with associative research type. The population of this study were 96 employees of the Palembang City Social Service. The sample of this research is calculated by using the Slovin formula, the error rate of 5\%, the sample size is 77 employees as respondents. The analysis model used in this research is descriptive statistical analysis, inferential and path analysis. This study aims to answer all problem formulations in the research object. The first conclusion, that leadership has a significant effect on employee morale. Second, the work environment, has a significant effect on employee morale. Third, leadership has a significant effect on the performance of the Palembang City Social Service Employees. Fourth, the work environment has a significant effect on employee performance. Fifth, morale has a significant effect on employee performance. Sixth, leadership through morale has a significant effect on employee performance. Seventh, the environment through morale has a significant effect on the performance of the Palembang City Social Service Employees. A more effective path is the path between leadership and employee performance through employee morale. Researchers provide recommendations, first, it must be maintained that employee morale has the greatest contribution to employee performance and employee work environment. Monitoring and evaluation must be carried out, because leadership towards employee morale is still of low value. Leaders should set a good example so that the performance of the Palembang City Social Service Employees needs to be improved. There needs to be supervision and evaluation from the leadership.
\end{abstract}

Keywords: Leadership, Work Environment, Work Spirit and Performance

\section{Pendahuluan}

Perilaku Kepemimpinan seorang pemimpin menjadi faktor penting yang mempengaruhi SDM. Kepemimpinan tercermin dari sikap dan perilaku pemimpin kepada bawahannya serta mengkoordinasikan tugas kerja ke setiap pegawai. Perilaku kepemimpinan yang dibentuk dari sikap dan pola tingkah laku didukung dengan adanya hubungan yang baik antara pimpinan dan bawahan maupun antara sesama bawahan. Perilaku kepemimpinan yang berorientasi hubungan difokuskan pada kualitas dari hubungan dengan bawahan, sedangkan perilaku kepemimpinan yang berorientasi tugas adalah tertuju hanya pada tugas-tugas yang harus diselesaikan bawahan tanpa memperhatikan kualitas dari hubungan itu sendiri. Komunikasi yang baik dari pimpinan kepada bawahannya pun dapat menjadi solusi bagi pegawai yang menghadapi pekerjaan yang akan diselesaikannya.

Lingkungan kerja pun menjadi faktor penting lainnya yang mempengaruhi SDM dalam melaksanakan pekerjaannya.Lingkungan kerja yang baik adalah yang aman, tenteram, bersih, tidak bising, terang dan bebas dari segala macam ancaman dan gangguan yang dapat menghambat pegawai untuk bekerja secara optimal. Lingkungan kerja yang kondusif akan membawa dampak baik bagi kelangsungan pegawai bekerja, sebaliknya, lingkungan kerja yang kurang kondusif akan membawa dampak negatif bagi kelangsungan pegawai dalam bekerja. Nitisemito (2002) mengelompokkan indikator lingkungan kerja menjadi tiga yakni

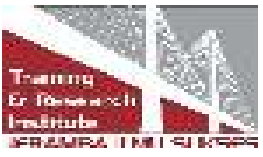


fasilitas kerja, hubungan dengan rekan kerja dan hubungan antara pegawai dengan atasan.Lingkungan kerja yang kondusif memberikan rasa aman dan memungkinkan para pegawai untuk dapat bekerja optimal. Lingkungan kerja dapat mempengaruhi emosi pegawai, jika pegawai menyenangi lingkungan kerja dimana ia bekerja, maka pegawai tersebut akan betah di tempat bekerjanya untuk melakukan aktivitas sehingga waktu kerja dipergunakan secara efektif dan optimal prestasi kerja pegawai juga tinggi. Lingkungan kerja tersebut mencakup hubungan kerja yang terbentuk antara sesama pegawai dan hubungan kerja antar bawahan dan atasan serta lingkungan fisik tempat pegawai bekerja.

Dinas Sosial Kota Palembang adalah Dinas yang memiliki penyelenggaraan urusan pemerintahan di bidang sosial. Setiap pegawainya memiliki tanggung jawab yang tinggi untuk memiliki semangat kerja yang tinggi pula untuk dapat menyelesaikan setiap tugas yang ada. Kepala Dinas selaku pemimpin tertinggi di Dinas Sosial dituntut memiliki kepemimpinan yang baik, memiliki sikap kepemimpinan yang berorientasi hubungan agar dapat menggerakkan setiap pegawainya untuk bekerja semaksimal mungkin sehingga dapat mewujudkan hasil kerja yang produktif. Kepala dinas dibantu oleh seorang Sekretaris Dinas, tiga orang Kepala Sub Bagian dan empat orang Kepala Bidang. Fenomena yang terjadi berdasarkan dari hasil observasi maupun wawancara seperti yang telah dijelaskan diatas yaitu kurangnya komunikasi dan pemberian apresiasi dari pimpinan kepada bawahan sehingga dapat menurunkan semangat kerja dari pegawai. Lingkungan kerja juga mempengaruhi semangat dari pegawai dalam melaksanakan pekerjaannya, di mana lingkungan kerja yang sempit mempengaruhi kenyamanan dalam bekerja, dikarenakan ruang kerja yang sempit mengakibatkan penyimpanan dokumen-dokumen sangat tidak efektif dan membutuhkan waktu jika dokumen tersebut diperlukan. Ini dapat mempengaruhi semangat pegawai dalam melaksanakan pekerjaannya. Berkaitan dengan latar belakang, maka penelitian ini akan menjawab permasalahan, yaitu akan mengetahui dan menganalisis pertama pengaruh kepemimpinan dan lingkungan kerja terhadap semangat kerja Pegawai. Kedua, pengaruh kepemimpinan, terhadap semangat kerja Pegawai. Ketiga, pengaruh lingkungan kerja terhadap semangat kerja Pegawai. Keempat, pengaruh kepemimpinan terhadap kinerja Pegawai. Kelima, pengaruh kepemimpinan terhadap kinerja Pegawai. Keenam, pengaruh kepemimpinan, lingkungan kerja, semangat kerja terhadap kinerja Pegawai. Ketujuh, pengaruh kepemimpinan dan lingkungan kerja terhadap kinerja Pegawai Dinas Sosial Kota Palembang.

\section{Tinjauan Literatur}

\subsection{Kepemimpinan}

\section{a. Pengertian Kepemimpinan}

Menurut Rivai (2004) kepemimpinan (leadership) adalah proses mempengaruhi atau memberi contoh kepada pengikut-pengikutnya lewat prses komunikasi dalam upaya mencapai tujuan organisasi. Keseluruhan tindakan guna mempengaruhi serta menggiatkan orang dalam usaha bersama untuk mencapai tujuan, atau dengan definisi yang lebih lengkap dapat dikatakan bahwa kepemimpinan adalah proses pemberian jalan yang mudah dari pada pekerjaan orang lain yang terorganisir dalam organisasi formal guna mencapai tujuan yang telah ditetapkan. Kartono (2008) berpendapat bahwa kepemimpinan merupakan salah relasi dan pengaruh antara pemimpin dengan yang dipimpin. Kepemimpinan tersebut muncul dan berkembang sebagai hasil dari interaksi otomatis anatara pemimpin dengan orang-orang yang dipimpinnya. Berdasarkan beberapa definisi di atas dapat disimpulkan bahwa kepemimpinan merupakan 
kemampuan seseorang untuk mempengaruhi dan mengarahkan orang secara efektif dan efisien dalam rangka mencapai tujuan.

\section{b. Indikator Kepemimpinan.}

Menurut Rifai (2009), menyatakan bahwa ada beberapa indikator kepemimpinan yang merupakan faktor-faktor yang mempengaruhi kepemimpinan, yaitu sebagai berikut:

a). Kesanggupan, pemimpin haruslah identik dengan diupayakan kesanggupan melakukan sesuatu yang melebihi orang lain, dengan mana pemimpin dapat mempengaruhi segala kegiatan yang dilakukan organisasi.

b). Ketegasan

c). Memecahkan permasalahan dengan capat dan tepat

d). Kepercayaan diri, kepecayaan diri yang didukung oleh kecerdasan, ilmu pengetahuan dan pengalaman

e). Adanya inisiatif, dalam berpikir jauh kedepan, selalu menginginkan kemajuan dan cara-cara yang baru.

\section{c. Kesuksesan Kepemimpinan}

Menurut Davis yang dikutip oleh Reksohadiprojo dan Handoko (2003), ada 10 ciri utama yang mempunyai pengaruh terhadap kesuksesan kepemimpinan dalam pemerintahan antara lain sebagai berikut :

a. Kecerdasan (Intelligence) Penelitian-penelitian pada umumnya menunjukkan bahwa seorang pemimpin yang mempunyai tingkat kecerdasan yang lebih tinggi daripada pengikutnya, tetapi tidak sangat berbeda.

b. Kedewasaan, Sosial dan Hubungan Sosial yang luas (Social maturity and Breadht) Pemimpin cenderung mempunyai emosi yang stabil dan dewasa atau matang, serta mempunyai kegiatan dan perhatian yang luas.

c. Motivasi diri dan dorongan berprestasi Pemimpin secara relatif mempunyai motivasi dan dorongan berprestasi yang tinggi, mereka bekerja keras lebih untuk nilai intrinsik.

d. Sikap-sikap hubungan manusiawi Seorang pemimpin yang sukses akan mengakui harga diri dan martabat pengikut-pengikutnya, mempunyai perhatian yang tinggi dan berorientasi pada bawahannya.

e. Memiliki Pengaruh yang Kuat Seorang pemimpin harus memiliki pengaruh yang kuat untuk menggerakkan orang lain atau bawahan agar berusaha mencapai tujuan kelompok secara sukarela.

f. Memiliki Pola Hubungan Yang Baik Seorang pemimpin sukses mampu menciptakan pola hubungan agar individu, dengan menggunakan wewenang dan pengaruhnya terhadap sekelompok orang agar bekerja sama dalam mencapai tujuan yang dikehendaki bersama.

g. Memiliki Sifat-Sifat Tertentu Seorang Pemimpin sukses memiliki sifat-sifat khusus seperti kepribadian baik, kemampuan tinggi dan kemampuan tinggi dan kemauan keras, sehingga mampu menggarakkan bawahannya. 
h. Memiliki Kedudukan atau Jabatan Seorang pemimpin selalu memiliki kedudukan atau jabatan dalam organisasi, baik di pemerintahan maupun di masyarakat karena kepemimpinan merupakan serangkaian kegiatan pemimpin yang tidak dapat dipisahkan dari kedudukan jabatan dan gaya atau perilaku pemimpin itu sendiri.

i. Mampu Berinteraksi Seorang pemimpin yang baik akan selalu berinteraksi secara baik dengan sesama pemimpin, bawahan dan masyarakat yang dipimpinnya, dalam situasi dan kondisi apa pun, buruk maupun menyenangkan.

j. Mampu Memberdayakan Seorang pemimpin yang sukses biasanya mampu memberdayakan bawahan dan masyarakat yang dipimpinnya.

\subsection{Lingkungan Kerja}

\section{a. Pengertian Lingkungan Kerja}

Menurut Render dan Heizer (2002), lingkungan kerja merupakan lingkungan fisik tempat karyawan bekerja yang mempengaruhi kinerja, keamanan dan mutu kehidupan kerja mereka. Lingkungan kerja merupakan keseluruhan sarana dan prasarana kerja yang ada di sekitar karyawan yang sedang melakukan pekerjaan yang dapat mempengaruhi pelaksanaan pekerjaan itu sendiri (Saydam, 2000).

Lingkungan kerja merupakan salah satu faktor yang cukup berpengaruh terhadap pekerjaan yang dilakukan oleh karyawan. Kondisi ligkungan kerja yang nyaman, aman dan mendukung akan membuat karyawan menjadi bersemangat dalam bekerja, dan hal ini dapat memberi pengaruh positif pada kinerjanya. Dengan adanya semangat dalam bekerja karyawan cenderung akan merasa puas dalam bekerja. Dan sebaliknya, lingkungan kerja yang banyak menimbulkan resiko atau tidak aman, dan tidak mendukung dalam pelaksanaan tugas yang dibebankan akan menyebabkan penurunan semangat kerja, kemungkinan dengan hal ini menyebabkan terjadi kesalahan dalam tugas, dan menurunnya produktivitas kerja (Nitisemito, 2016). Lingkungan kerja adalah segala sesuatu yang ada disekitar para pekerja dan dapat mempengaruhi dirinya dalam melakukan tugas-tugas yang dibebankan (Nitisemito, 2016). Karena lingkungan kerja dapat berpengaruh terhadap pekerjaan yang dilakukan, maka setiap perusahaan haruslah mengusahakan agar faktor-faktor yang termasuk lingkungan kerja diusahakan sedemikian rupa sehingga mempunyai pengaruh yang positif. Lingkungan kerja menurut Kenneth (2010), adalah suatu lingkungan dimana pegawai bekerja, lingkungan kerja adalah hal-hal yang berhubungan atau ada dalam lingkungan pekerjaannya, dan dapat mempengaruhi dirinya dalam menjalankan tugas yang diberikan kepadanya, baik itu yang berhubungan dengan kebendaan atau fisik maupun yang berhubungan dengan manusia. Lingkungan kerja adalah keadaan dimana tempat kerja yang baik meliputi fisik atau non fisik, yang dapat memberikan kesan menyenangkan, aman, tentram, dan lain sebagainya, (Handoko, 2012). Menurut Mangkunegara (2012), lingkungan kerja merupakan segala sesuatu yang ada di sekitar pekerja dan dapat mempengaruhi dalam bekerja, meliputi pengaturan penerangan, pengaturan suhu udara, pengontrolan suara bising, pengaturan ruang gerak, dan pengaturan keamanan tempat kerja.

Berdasarkan beberapa pendapat, dapat disimpulkan bahwa lingkungan kerja adalah keadaan dan suasana di sekitar tempat pegawai melakukan aktivitas kerjanya, baik fisik dan non fisik, yang dapat mempengaruhi kinerjanya.

b. Indikator Lingkungan Kerja

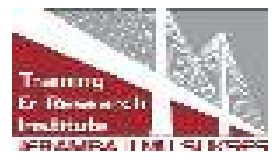


Menurut Mangkunegara (2012), indikator yang dapat digunakan untuk mengukur lingkungan kerja adalah : 1). Penerangan/cahaya di tempat kerja. Cahaya lampu sangat besar manfaatnya bagi karyawan guna mendapat keselamatan dan kelancaran kerja. Jika cahaya lampu tidak memadai, akan berpengaruh terhadap aktivitas karyawan, dalam melaksanakan tugas-tugasnya mengalami kesalahan serta kurang efisien, sehingga tujuan organisasi sulit tercapai. 2). Temperatur/suhu udara di tempat kerja. Setiap anggota tubuh manusia mempunyai temperatur yang berbeda. Manusia selalu mempertahankan tubuhnya dalam keadan normal, dengan suatu sistem tubuh yang sempurna sehingga dapat menyesuaikan diri dengan perubahan yang terjadi di luar tubuh. Tetapi kemampuan untuk menyesuaikan diri tersebut ada batasnya. Manusia dapat menyesuaikan dirinya dengan temperatur luar, jika perubahan temperatur tubuh tidak lebih dari $20 \%$ untuk kondisi panas, dan 35\% untuk kondisi dingin dari keaadan normal tubuh. 3). Kelembaban di tempat kerja. Kelembaban adalah banyaknya air yang terkandung dalam udara, biasanya dinyatakan dalam persentase. Kelembaban ini dipengaruhi oleh temperatur udara. Jika keadaan temperatur udara sangat panas dan kelembaban tinggi, akan menimbulkan pengurangan panas dari tubuh secara besar. 4). Sirkulasi udara di tempat kerja. Sirkulasi udara di tempat kerja dapat mempengaruhi kenyamanan pegawai dalam melakukan pekerjaannya, dengan udara yang bersih dan cukupnya oksigen di sekitar tempat kerja, akan memberikan kesejukan dan kesegaran pada jasmani, serta mempercepat pemulihan tubuh setelah lelah bekerja. 5). Kebisingan di tempat kerja. Kebisingan merupakan suatu bunyi yang tidak dikehendaki oleh telinga, kaena jika dalam jangka yang panjang dapat mengganggu ketenangan dalam bekerja, merusak pendengaran, dan menimbulkan kesalahan dalam berkomunikasi. Hal ini dapat mengganggu pekerjaan yang membutuhkan konsentrasi tinggi, dan mengakibatkan pekerjaan yang dilakukan tidak efisien. 6). Tata warna di tempat kerja. Menata warna di tempat kerja perlu dipelajari dan direncanakan dengan sebaik mungkin, karena pada kenyataannya tata warna tidak dapat dipisahkan dengan penataan dekorasi. Hal ini dapat dimaklumi karena pengaruh warna mempunyai pengaruh besar terhadap perasaan manusia. 7). Musik di tempat kerja. Musik yang nadanya lembut sesuai dengan suasana, waktu dan tempat dapat membangkitkan dan merangsang pegawai untuk bekerja. Oleh karena itu, lagu-lagu perlu dipilih dengan selektif untuk dikumandangkan di tempat kerja. 8). Keamanan di tempat kerja. Guna menjaga tempat dan kondisi lingkungan kerja tetap dalam keadaan aman, perlu diperhatikan adanya keamanan dalam bekerja. Oleh karena itu faktor keamanan perlu diwujudkan keberadaannya. Tempat kerja yang aman akan memberikan ketenangan bagi para pegawai dalam melakukan pekerjaannya.

Menurut Nitisemito, (2010) indikator lingkungan kerja adalah : 1). Suhu udara di tempat kerja. Suhu udara temapt kerja adalah keadaan panas udara pada tempat kerja. Tempat kerja yang sejuk dan nyaman membuat karyawan nyaman dan betah dalam bekerja. 2). Sirkulasi Udara. Oksigen merupakan gas yang dibutuhkan oleh mahluk hidup, yaitu untuk proses metabolisme. Udara di sekitar tempat kerja dikatakan kotor jika kadar oksigen dalam udara tersebut telah berkurang dan telah bercampur dengan gas atau bau-bauan yang berbahaya bagi kesehatan tubuh. Sirkulasi udara yang baik berpengaruh terhadap kenyamanan pegawai dalam bekerja. 3). Dekorasi Tempat Kerja. Dekorasi ada hubungannya dengan tata warna yang baik, karena dekorasi tidak hanya berhubungan dengan hiasan ruang kerja, akan tetapi berhubungan juga dengan cara mengatur tata letak, tata warna, perlengkapan, dan lainnya untuk bekerja. 4). Hubungan Kerja. Hubungan dengan rekan kerja yaitu hubungan yang harmonis dan tanpa adanya saling intrik diantara sesama rekan kerja. Salah satu faktor yang dapat mempengaruhi pegawai tetap tinggal dalam satu organisasi adalah adanya hubungan yang harmonis diantara rekan kerja. 
c. Hubungan Lingkungan kerja dengan kinerja

Lingkungan kerja yang tidak sesuai akan menyebabkan gangguan bagi tenaga kerja yang ada di lingkungan kerja tersebut, dan pada akhirnya juga akan mempengaruhi produktivitas, (Haryono, 2008). Lingkungan kerja harus menjadi perhatian mengingat sebagian besar waktu pegawai tiap harinya dihabiskan di tempat kerja. Lingkungan kerja yang tidak kondusif dan kurang mendukung pelaksanaan aktivitas kerja dari karyawan, akan mempengaruhi tingkat keberhasilan karyawan terhadap kerjanya, begitu pula dengan ketersediaan fasilitas yang kurang, akan mempengaruhi efektifitas dan efisiensi waktu kerja. Lingkungan kerja merupakan pendukung keberhasilan pelaksanaan kerja, semakin baik kondisi lingkungan kerja maka semakin baik pula hasil pekerjaannya.

\subsection{Semangat Kerja}

\section{a. Pengertian Semangat Kerja}

Semangat kerja yang tinggi merupakan suatu reaksi yang positif dengan kata lain dapat menyelesaikan pekerjaan dengan hasil yang lebih baik, maka semangat kerja mempunyai pengaruh terhadap aktivitas kantor, sehingga kantor atau organisasi menginginkan pegawai yang mempunyai semangat kerja yang tinggi (Hasibuan, 2009). Denyer dalam Moekijat (2003) menjelaskan kata semangat (morale) itu mulamula dipergunakan dalam kalangan militer untuk menunjukkan keadaan moral pasukan, akan tetapi sekarang mempunyai arti yang lebih luas dan dapat dirumuskan sebagai sikap bersama para pekerja terhadap satu sama lain, terhadap atasan, terhadap manajemen, atau pekerjaan. Nitisemito (2002) berpendapat bahwa semangat kerja adalah melakukan pekerjaan secara lebih giat sehingga pekerjaan dapat diharapkan lebih cepat dan lebih baik. Hasibuan (2009) mengatakan semangat kerja sebagai keinginan dan kesungguhan seseorang mengerjakan pekerjaanya dengan baik serta berdisiplin untuk mencapai prestasi kerja yang maksimal. Sastrohadiwiryo (2003) mengatakan semangat kerja dapat diartikan sebagai suatu kondisi mental, atau perilaku individu tenaga kerja dan kelompokkelompok yang menimbulkan kesenangan yang mendalam pada diri tenaga kerja untuk bekerja dengan giat dan konsekuen dalam mencapai tujuan yang telah ditetapkan kantor. Siagian (2003) mengartikan bahwa semangat kerja pegawai menunjukkan sejauh mana pegawai bergairah dalam melakukan tugas dan tanggung jawabnya di dalam kantor. Menurut beliau, semangat kerja dapat dilihat dari kehadiran, kedisiplinan, ketepatan waktu, target kerja, gairah kerja serta tanggung jawab yang telahdiberikan kepada pegawai tersebut.

Definisi-definisi di atas, dapat disimpulkan bahwa semangat kerja ialah keinginan dan kesungguhan seseorang dalam melakukan pekerjaan secara giat dan baik serta berdisiplin tinggi untuk mencapai prestasi kerja ng maksimal dan juga mencapai tujuan yang telah ditetapkan kantor. Dengan meningkatnya semangat dan gairah kerja, maka pekerjaan akan lebih cepat diselesaikan dan semua pengaruh buruk dari menurunnya semangat kerja seperti absensi dan selanjutnya akan dapat diperkecil dan selanjutnya menaikkan semangat dan gairah kerja yang berarti diharapkan juga meningkatkan produktivitas karyawan. Semangat kerja dapat diartikan sebagai semacam pernyataan ringkas dari kekuatan-kekuatan psikologis yang beraneka ragam yang menekan sehubungan dengan pekerjaan mereka. Semangat kerja dapat diartikan juga sebagai suatu iklim atau suasana kerja yang terdapat di dalam suatu organisasi yang menunjukkan rasa kegairahan di dalam melaksanakan pekerjaan dan mendorong mereka untuk bekerja secara lebih baik dan lebih produktif.

\section{b. Faktor-Faktor Yang Mempengaruhi Semangat Kerja}


Menurut Nawawi (2018), faktor-faktor yang mempengaruhi tinggi rendahnya semangat kerja adalah: 1). Minat seseorang terhadap pekerjaan yang dilakukan. Seseorang yang berminat dalam pekerjaannya akan dapat meningkatkan semangat kerja. 2). Faktor gaji atau upah tinggi akan meningkatkan semangat kerja seseorang. 3). Status sosial pekerjaan. Pekerjaan yang memiliki status sosial yang tinggi dan memberi posisi yang tinggi dapat menjadi faktor penentu meningkatnya semangat kerja. 4). Suasana kerja dan hubungan dalam pekerjaan. Penerimaan dan penghargaan dapat meningkatkan semangat kerja. 5). Tujuan pekerjaan. Tujuan yang mulia dapat mendorong semangat kerja seseorang.

\section{c. Indikator Semangat Kerja}

Menurut Nitisemito (2016), berdasarkan indikasi yang menunjukkan kecenderungan rendahnya semangat kerja, maka karakteristik semangat kerja dapat diketahui dari tiga indikator yaitu 1). Disiplin. Disiplin merupakan suatu keadaan tertip karena orang - orang yang bergabung dalam suatu organisasi tunduk dan taat kepada aturan yang ada serta melaksanakan dengan senang hati. 2). Kerja sama. Kerja sama diartikan sebagai tindakan kolektif seseorang dengan orang lain yang dapat dilihat dari kesediaan para karyawan untuk bekerja sama dengan teman - teman sekerja dan atasan mereka sehubung dengan tugas masing - masing. Kerja sama adalah refleksi dari semangat dan akan baik jika semangat tinggi. Proses kerja sama mengandung segi relasi, interaksi, partisipasi, kontribusu setiap individu, dan masing - masing mereka menyumbangkan ide pikirnya.3). Kepuasan kerja. Kepuasan mempunyai kontribusi yang sangat besar terhadap produktivitas kerja. Setiap pekerja mempunyai dorongan untuk bekerja adalah kerja adalah pusat dari kehidupan dan kerja adalah sejumlah aktivitas fisik dan mental untuk mengerjakan suatu pekerjaan.

\subsection{Kinerja Pegawai}

\section{a. Pengertian Kinerja Pegawai}

Kinerja merupakan hasil pekerjaan yang mempunyai hubungan kuat dengan tujuan strategis organisasi, kepuasan konsumen, dan memberikan kontribusi pada ekonomi (Wibowo, 2010). "Kinerja merupakan hasil pekerjaan yang mempunyai hubungan kuat dengan tujuan strategis organisasi, kepuasan konsumen, dan memberikan kontribusi pada ekonomi". Menurut Hasibuan (2014) kinerja merupakan hasil kerja yang dicapai seseorang dalam melaksanakan tugas-tugas yang dibebankan kepadanya didasarkan atas kecakapan, pengalaman, kesungguhan serta waktu. Kinerja mempunyai makna yang lebih luas, bukan hanya menyatakan hasil kerja, namun juga bagaimana proses kerja berlangsung. Kinerja adalah tentang melakukan pekerjaan tersebut, apa yang dikerjakan dan bagaimana cara mengerjakannya yang kemudian menghasilkan pekerjaan yang mempunyai hubungan kuat dengan tujuan strategi perusahaan serta memberikan kontribusi ekonomi. Menurut Siagian (2009) menjelaskan bahwa bagi individu penilaian kinerja berperan sebagai umpan balik tentang berbagai hal seperti kemampuan, keletihan, kekurangan dan potensinya yang pada gilirannya bermanfaat untuk menentukan tujuan, alur, rencana dan pengembangan karirnya. Sedangkan bagi organisasi, hasil penilaian kinerja sangat penting dalam kaitannya dengan pengambilan keputusan tentang berbagai hal seperti identifikasi kebutuhan program pendidikan dan pelatihan, rekrutmen, seleksi, program pengenalan, penempatan, promosi, sistem balas jasa, serta berbagai aspek lain dalam proses manajemen sumber daya manusia. Busro (2018) mengatakan bahwa pengertian kinerja adalah kemampuan kerja di dalam terminologi kualitas dan kuantitas. Kinerja merupakan prestasi kerja (performance) baik bersifat kuantitas maupun kualitas yang dicapai

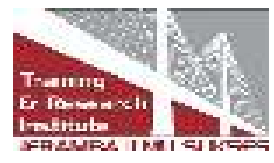


seseorang selama periode tertentu, biasa dalam waktu satu bulan. Menurut Kasmir (2016) kinerja adalah hasil kerja dan perilaku kerja yang telah dicapai dalam menyelesaikan tugastugas dan tanggung jawab yang diberikan dalam suatu periode tertentu. Berdasarkan pengertian-pengertian di atas, dapat ditarik kesimpulan bahwa kinerja adalah suatu hasil kerja yang dicapai oleh seorang pegawai/karyawan sesuai dengan standard dan kreteria yang telah ditetapkan dalam kurun waktu tertentu untuk pencapaian tujuan organisasi.

\section{b. Dimensi Kinerja}

Sutrisno (2010) menyebutkan ada enam hal yang dapat digunakan dalam mengukur kinerja, yaitu : 1). Kualitatif (Quality), merupakan tingkat proses atau hasil pelaksanaan kegiatan mendekati kesempurnaan atau mendekati tujuan yang diharapkan. 2). Kuantitas (Quantity), merupakan jumlah yang dihasilkan, misalnya jumlah rupiah, unit, dan siklus kegiatan yang dilakukan. 3). Ketepatan waktu (Timelines), merupakan suatu kegiatan diselesaikan pada waktu yang dikehendaki, dengan memerhatikan koordinasi output lain serta waktu yang tersedia untuk kegiatan orang lain. 4). Efektivitas sumberdaya (Cost Effectiveness), merupakan tingkat penggunaan sumber daya organisasi dimaksimalkan untuk mencapai hasil tertinggi atau pengurangan kerugian dari setiap unit penggunaan sumber daya.5). Kemampuan pengawas (Need for Supervision), merupakan tingkat kemampuan seorang pekerja dapat melaksanakan suatu fungsi pekerjaan tanpa memerlukan pengawasan seorang supervision untuk mencegah tindakan yang kurang diinginkan. 6). Hubungan pribadi (Interpersonal Impact), merupakan tingkat kemampuan pegawai memelihara harga diri, nama baik, dan kerjasama diantara rekan kerja dan bawahan.

\section{c. Indikator - Indikator Kinerja}

Menurut Wibowo (2014) terdapat beberapa indikator dalam kinerja yaitu: a). Tujuan, merupakan keadaan yang berbeda yang secara aktif dicari oleh seseorang individu atau organisasi untuk dicapai. b). Standar, mempunyai arti penting karena memberitahukan kapan suatu tujuan dapat diselesaikan. c). Umpan balik, balik melaporkan kemajuan baik kualitas maupun kuantitas dalam mencapai tujuan yang didefinisikan oleh standar. d). Alat dan Sarana, merupakan sumber daya yang dapat dipergunakan untuk membantu menyelesaikan tujuan dengan sukses. e). Kompetensi, merupakan persyaratan dalam kinerja. Kompetensi merupakan kemampuan yang dimiliki oleh seseorang untuk menjalankan pekerjaan yang diberikan kepadanya dengan baik. f). Motif, merupakan alasan/pendorong bagi seseorang untuk melakukan sesuatu. g). Peluang, Pekerja perlu mendapatkan kesempatan untuk menunjukan prestasi.

\subsection{Kerangka Pemikiran}

Kerangka berpikit dalam penelitian ini menggunakan kajian deskriptif, dengan kata lain bahwa kajian yang penulis terapkan menggunakan teori-teori yang dikemukanan para ahli. Dari pengertian dan hasil penelitian yang relevan dapat di dijelaskan secara paradigma alur pikir sebagai berikut : 


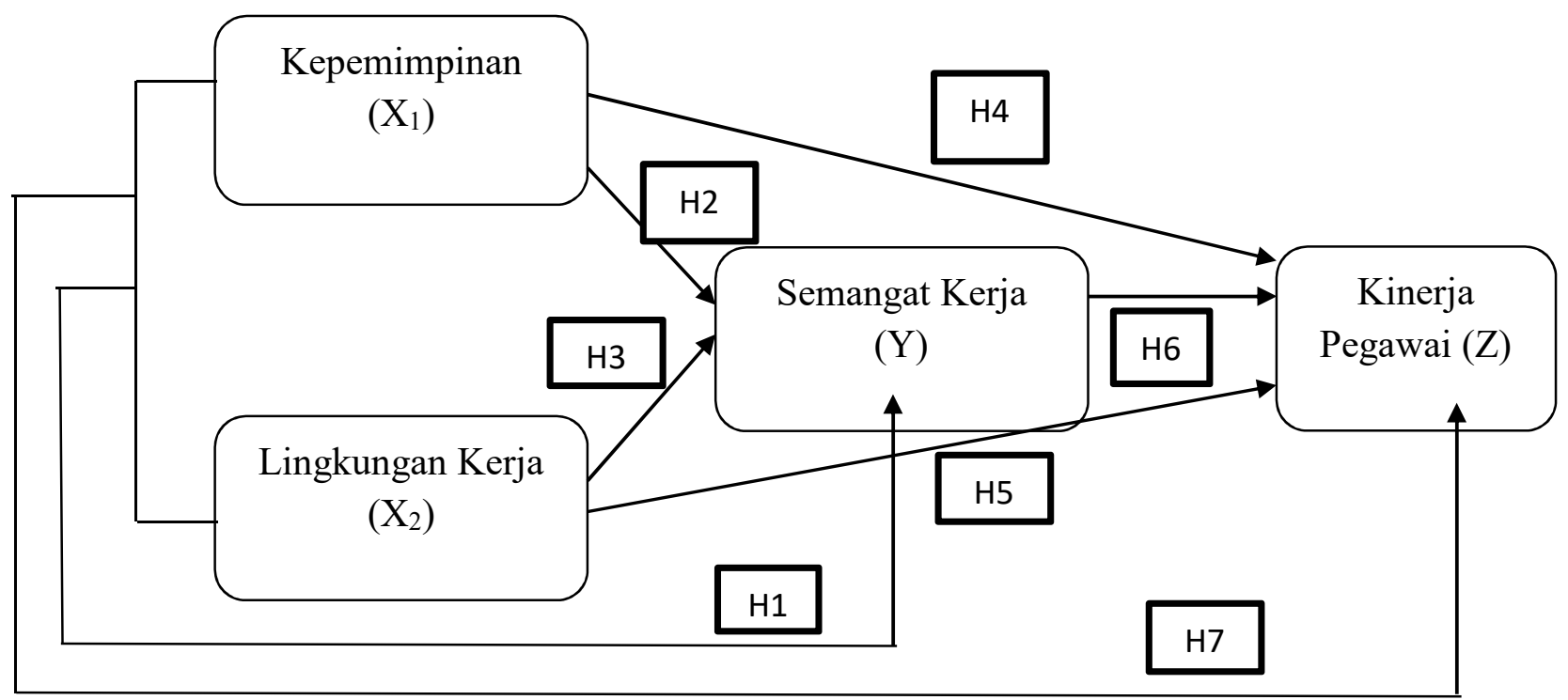

Gambar 1. Kerangka Pemikiran

\section{Metode Penelitian}

Pemilihan metode dalam suatu penelitian haruslah ditentukan dengan tepat agar dapat menghasilkan hasil penelitian yang lebih akurat. (Sugiyono 2014) Jenis penelitian yang digunakan adalah penelitian Asosiatif, karena penelitian ini bertujuan untuk mengetahui Pengaruh Kepemimpinan, Lingkungan Kerja terhadap Semangat Kerja yang berdampak pada Kinerja Pegawai Dinas Sosial Kota Palembang. Operasionalisasi variabel penelitian ini, seperti tabel berikut:

Tabel. 1. Operasionalisasi Variabel

\begin{tabular}{|c|c|c|c|c|}
\hline Variabel & Definisi & Indikator & Item & Skala \\
\hline $\begin{array}{l}\text { Kepemimpinan } \\
\left(\mathrm{X}_{1}\right)\end{array}$ & $\begin{array}{l}\text { pimpinan yang berkemampuan } \\
\text { lebih dari bawahannya, } \\
\text { meyakinkan dan menggerakkan } \\
\text { pegawai agar mau bekerja sama di } \\
\text { bawah kepemimpinannya di Dinas } \\
\text { Sosial Kota Palembang }\end{array}$ & $\begin{array}{l}\text { 1. Kesanggupan } \\
\text { 2. Ketegasan } \\
\text { 3. Percaya diri }\end{array}$ & $\begin{array}{l}1-3 \\
4-6 \\
7-9\end{array}$ & Ordinal \\
\hline $\begin{array}{l}\text { Lingkungan } \\
\text { kerja }\left(X_{2}\right)\end{array}$ & $\begin{array}{l}\text { keadaan dan suasana di sekitar } \\
\text { tempat pegawai melakukan } \\
\text { aktivitas kerjanya, baik fisik dan } \\
\text { non fisik, yang dapat } \\
\text { mempengaruhi kinerjanya di Dinas } \\
\text { Sosial Kota Palembang }\end{array}$ & $\begin{array}{l}\text { 1.Suhu udara di } \\
\text { tempat kerja. } \\
\text { 2.Sirkulasi udara } \\
\text { 3.Dekorasi tempat } \\
\text { kerja } \\
\text { 4.Hubungan kerja. }\end{array}$ & $\begin{array}{l}1-2 \\
3-4 \\
5-6 \\
7-8\end{array}$ & Ordinal \\
\hline $\begin{array}{l}\text { Semangat kerja } \\
\text { (Y) }\end{array}$ & $\begin{array}{l}\text { keinginan dan kesungguhan } \\
\text { pegawai dalam melakukan } \\
\text { pekerjaan secara giat dan baik serta } \\
\text { berdisiplin tinggi untuk mencapai } \\
\text { prestasi kerja yang maksimal dan }\end{array}$ & $\begin{array}{l}\text { 1. Disiplin } \\
\text { 2. Kerjasama } \\
\text { 3. Kepuasan kerja }\end{array}$ & $\begin{array}{l}1-3 \\
4-6 \\
7-9\end{array}$ & Ordinal \\
\hline
\end{tabular}




\begin{tabular}{|c|c|c|c|c|}
\hline & $\begin{array}{l}\text { juga mencapai tujuan yang telah } \\
\text { ditetapkan Dinas Sosial Kota } \\
\text { Palembang. }\end{array}$ & & & \\
\hline $\begin{array}{l}\text { Kinerja } \\
\text { Pegawai (Z) }\end{array}$ & $\begin{array}{l}\text { suatu hasil kerja yang dicapai } \\
\text { oleh seorang pegawai sesuai } \\
\text { dengan standard dan kreteria } \\
\text { yang telah ditetapkan dalam } \\
\text { kurun waktu tertentu untuk } \\
\text { pencapaian tujuan di Dinas } \\
\text { Sosial Kota Palembang }\end{array}$ & $\begin{array}{l}\text { 1. Tujuan } \\
\text { 2. Standar } \\
\text { 3. Kompetensi }\end{array}$ & $\begin{array}{l}1-3 \\
4-6 \\
7-9\end{array}$ & Ordinal \\
\hline
\end{tabular}

Sumber: Gagasan berdasar Teori, Wibowo, 2014. Hasibuan, 2014, Rifai, 2009

Populasi adalah Pegawai Dinas Sosial Kota Palembang yang berjumlah 96 pegawai. Untuk menentukan sampel penelitian, Slovin memasukkan unsur kelonggaran ketidaktelitian karena kesalahan pengambilan sampel yang masih dapat ditoleransi. Teknik pengambilan sampel yang digunakan adalah Teknik Probability Sampling yaitu dimana setiap anggota populasi mempunyai peluang sama untuk dipilih menjadi anggota sampel dengan cara Stratified Random Sampling (Husein, 2019). Responden sampel dalam penelitian ini berjumlah 77 responden. Kuesioner merupakan teknik pengumpulan data yang dilakukan dengan cara memberi seperangkat pertanyaan/pernyataan tertulis kepada responden untuk dijawabnya (Sugiyono 2012). Menggunakan Skor Data Skala Likert jawaban, Sangat Setuju 5, Setuju 4, Netral 3, Tidak Setuju 2 dan Sangat Tidak Setuju 1.

Uji validitas dilakukan untuk mengukur ketepatan instrumen yang digunakan dalam suatu penelitian. Uji Validitas dapat dilakukan dengan menghitung korelasi antara skor masingmasing item pertanyaan dengan total skor. Kriteria yang digunakan dalam menentukan valid tidaknya pernyataan yang digunakan dalam penelitian ini adalah, tingkat signifikasi sebesar 0,05 , derajat kebebasan $(\mathrm{df})=\mathrm{n}-2=30-2=28$, didapat $\mathrm{r}$ tabel $=0,3610$. Uji Reliabelitas digunakan untuk melihat kekonsistenan dan stabilitas data atau temuan. Uji Reliabilitas yang digunakan dalam penelitian ini adalah metode internal. Metode internal dilakukan dengan melihat besarnya Croanbach Alpha ( $\mathrm{r}$ alpha) yang perhitungannya menggunakan prosedur Reliability Analisys pada pengaruh X1,X2,X3 terhadap Y. Menurut Latan Hengky (2012:48) dalam penelitian Confirmatory Research secara umum reliabilitas dapat diterima jika nilai Cronbach Alpha $>0,7$.

Analisis inferensial dalam penelitian ini digunakan untuk melakukan pengujian hipotesis.Analisis infensial yang digunakan yaitu pendekatan adalah Analisis Jalur (Path Analysis). Model path analysis digunakan untuk menganalisis pola hubungan antar variabel dengan tujuan untuk mengetahui pengaruh langsung maupun tidak langsung seperangkat variabel bebas (eksogen) terhadap variabel terikat (endogen) (Buchari Alma, 2010). Metode penelitian kuantitatif dengan teknik analisis yang akan digunakan adalah analisis Structural Equation Modelling (SEM) dengan menggunakan program software AMOS 5.0.Sebagai salah satu teknik analisis multivarite, SEM memungkinkan dilakukannya analisis terhadap serangkaian hubungan secara simultan sehingga memberikan efisiensi secara statistik (Ferdinand, 2002). 


\section{Hasil dan Pembahasan}

\subsection{Hasil penelitian}

a. Uji Validitas

1). Variabel Kinerja Pegawai (Z).

Tabel 2. Uji Validitas Variabel Kinerja (Z)

\begin{tabular}{cccc}
\hline Item & $\begin{array}{c}\text { Corrected Item- } \\
\text { Total Correlation }\end{array}$ & $\begin{array}{c}\text { r-tabel } \\
(\mathrm{N}=30)\end{array}$ & Keterangan \\
\hline $\mathbf{Z}_{\mathbf{1 . 1}}$ & 0.968 & 0,3610 & Valid \\
$\mathbf{Z}_{\mathbf{1 . 2}}$ & 0.955 & 0,3610 & Valid \\
$\mathbf{Z}_{\mathbf{1 . 3}}$ & 0.951 & 0,3610 & Valid \\
$\mathbf{Z}_{\mathbf{1 . 4}}$ & 0.955 & 0,3610 & Valid \\
$\mathbf{Z}_{\mathbf{1 . 5}}$ & 0.963 & 0,3610 & Valid \\
$\mathbf{Z}_{\mathbf{1 . 6}}$ & 0.924 & 0,3610 & Valid \\
$\mathbf{Z}_{\mathbf{1 . 7}}$ & 0.866 & 0,3610 & Valid \\
$\mathbf{Z}_{\mathbf{1 . 8}}$ & 0.887 & 0,3610 & Valid \\
$\mathbf{Z}_{\mathbf{1 . 9}}$ & 0.948 & 0,3610 & Valid \\
\hline
\end{tabular}

Hasil uji validitas akan variabel Variabel Kinerja Pegawai $(Z)$ dimana tidak terdapat item-item yang memiliki nilai corrected Item-Total Correlation $>0,3610$ (nilai r tabel dengan $\mathrm{N}=30$ ), sehingga semua item dalam variable Kinerja Pegawai $(Z)$ ini dapat dipergunakan, sehingga pernyataan untuk variable Kinerja Pegawai $(Z)$ terdiri dari 9 item, yang terdiri dari $: Z_{1.1}, Z_{1.2}$, $\mathrm{Z}_{1.3}, \mathrm{Z}_{1.4}, \mathrm{Z}_{1.5}, \mathrm{Z}_{1.6}, \mathrm{Z}_{1.7}, \mathrm{Z}_{1.8}, \mathrm{Z}_{1.9}$.

2). Variabel Semangat Kerja Pegawai (Y).

Tabel 3. Uji Validitas Variabel Semangat Kerja Pegawai (Y)

\begin{tabular}{cccc}
\hline Item & $\begin{array}{c}\text { Corrected Item- } \\
\text { Total Correlation }\end{array}$ & $\begin{array}{c}\text { r-tabel } \\
(\mathrm{N}=30)\end{array}$ & Keterangan \\
\hline $\mathbf{Y}_{\mathbf{1 . 1}}$ & 0,940 & 0,3610 & Valid \\
$\mathbf{Y}_{\mathbf{1 . 2}}$ & 0,955 & 0,3610 & Valid \\
$\mathbf{Y}_{\mathbf{1 . 3}}$ & 0,916 & 0,3610 & Valid \\
$\mathbf{Y}_{\mathbf{1 . 4}}$ & 0,934 & 0,3610 & Valid \\
$\mathbf{Y}_{\mathbf{1 . 5}}$ & 0,928 & 0,3610 & Valid \\
$\mathbf{Y}_{\mathbf{1 . 6}}$ & 0,801 & 0,3610 & Valid \\
$\mathbf{Y}_{\mathbf{1 . 7}}$ & 0,774 & 0,3610 & Valid \\
$\mathbf{Y}_{\mathbf{1 . 8}}$ & 0,893 & 0,3610 & Valid \\
$\mathbf{Y}_{\mathbf{1 . 9}}$ & 0,905 & 0,3610 & Valid \\
\hline
\end{tabular}

Dari hasil pengujian validitas terhadap item-item pada variable Variabel Semangat Kerja Karyawan (Y) seperti terlihat pada Tabel diatas, didapat hasil uji nilai hitung corrected ItemTotal Correlation $>0,3610$ sehingga seluruh item dinyatakan valid, sehingga pernyataan untuk Variabel Semangat Kerja Karyawan (Y) terdiri dari 9 item, yaitu : $\mathrm{Y}_{1.1}, \mathrm{Y}_{1.3}, \mathrm{Y}_{1.3}, \mathrm{Y}_{1.4}, \mathrm{Y}_{1.5}$, $\mathrm{Y}_{1.6}, \mathrm{Y}_{1.7}, \mathrm{Y}_{1.8}, \mathrm{Y}_{1.9}$ 
3). Variabel Lingkungan Kerja Pegawai $\left(\mathrm{X}_{2}\right)$

Tabel 4. Uji Validitas Variabel Lingkungan Kerja Pegawai $\left(\mathrm{X}_{2}\right)$

\begin{tabular}{cccc}
\hline Item & $\begin{array}{c}\text { Corrected Item- } \\
\text { Total Correlation }\end{array}$ & $\begin{array}{c}\text { r-tabel } \\
(\mathrm{N}=30)\end{array}$ & Keterangan \\
\hline $\mathbf{X}_{\mathbf{2 . 1}}$ & 0,973 & 0,3610 & Valid \\
$\mathbf{X}_{2.2}$ & 0,972 & 0,3610 & Valid \\
$\mathbf{X}_{2.3}$ & 0,971 & 0,3610 & Valid \\
$\mathbf{X}_{2.4}$ & 0,967 & 0,3610 & Valid \\
$\mathbf{X}_{2.5}$ & 0,944 & 0,3610 & Valid \\
$\mathbf{X}_{2.6}$ & 0,954 & 0,3610 & Valid \\
$\mathbf{X}_{2.7}$ & 0,970 & 0,3610 & Valid \\
$\mathbf{X}_{\mathbf{2 . 8}}$ & 0,964 & 0,3610 & Valid \\
\hline
\end{tabular}

Dari hasil pengujian validitas terhadap item-item pada Variabel Lingkungan Kerja Pegawai $\left(\mathrm{X}_{2}\right)$ seperti terlihat pada Tabel diatas, didapat hasil uji nilai hitung corrected Item-Total Correlation $>0,3610$ sehingga seluruh item dinyatakan valid, sehingga pernyataan untuk Variabel Lingkungan Kerja Pegawai $\left(\mathrm{X}_{2}\right)$ terdiri dari 8 item, yaitu : $\mathrm{X}_{2.1}, \mathrm{X}_{2.2}, \mathrm{X}_{2.3}, \mathrm{X}_{2.4}, \mathrm{X}_{2.5}$, $\mathrm{X}_{2.6}, \mathrm{X}_{2.7}, \mathrm{X}_{2.8}$

4). Variabel Kepemimpinan $\left(\mathrm{X}_{1}\right)$.

Tabel 5. Uji Validitas Variabel Kepemimpinan $\left(\mathrm{X}_{1}\right)$

\begin{tabular}{cccc}
\hline Item & $\begin{array}{c}\text { Corrected Item- } \\
\text { Total Correlation }\end{array}$ & $\begin{array}{c}\text { r-tabel } \\
(\mathrm{N}=30)\end{array}$ & Keterangan \\
\hline $\mathbf{X}_{\mathbf{1 . 1}}$ & 0,956 & 0,3610 & Valid \\
$\mathbf{X}_{\mathbf{1 . 2}}$ & 0,937 & 0,3610 & Valid \\
$\mathbf{X}_{\mathbf{1 . 3}}$ & 0,904 & 0,3610 & Valid \\
$\mathbf{X}_{1.4}$ & 0,894 & 0,3610 & Valid \\
$\mathbf{X}_{\mathbf{1 . 5}}$ & 0,911 & 0,3610 & Valid \\
$\mathbf{X}_{\mathbf{1 . 6}}$ & 0,909 & 0,3610 & Valid \\
$\mathbf{X}_{\mathbf{1 . 7}}$ & 0,883 & 0,3610 & Valid \\
$\mathbf{X}_{\mathbf{1 . 8}}$ & 0,902 & 0,3610 & Valid \\
$\mathbf{X}_{\mathbf{1 . 9}}$ & 0,974 & 0,3610 & Valid \\
\hline
\end{tabular}

Dari hasil pengujian validitas terhadap item-item pada variable Variabel Kepemimpinan $\left(\mathrm{X}_{1}\right)$ seperti terlihat pada Tabel diatas, didapat hasil uji nilai hitung corrected Item-Total Correlation $>0,3610$ sehingga seluruh item dinyatakan valid, sehingga pernyataan untuk Variabel Kepemimpinan $\left(\mathrm{X}_{1}\right)$ terdiri dari 9 item, yaitu : $\mathrm{X}_{1.1}, \mathrm{X}_{1.2}, \mathrm{X}_{1.3}, \mathrm{X}_{1.4}, \mathrm{X}_{1.5}, \mathrm{X}_{1.6}, \mathrm{X}_{1.7}, \mathrm{X}_{1.8}, \mathrm{X}_{1.9}$. 
b. Uji Reliabilitas

Tabel. 6. Uji Reliabilitas Variabel

\begin{tabular}{crr}
\hline Variabel & $\begin{array}{c}\text { Cronbach's } \\
\text { Alpha }\end{array}$ & N of Items \\
\hline Kepemimpinan $\left(\mathrm{X}_{1}\right)$ & .981 & 10 \\
Lingkungan Kerja & .992 & 9 \\
Pegawai $\left(\mathrm{X}_{2}\right)$ & & \\
$\begin{array}{c}\text { Semangat Kerja } \\
\text { Pegawai }(\mathrm{Y})\end{array}$ & .974 & 10 \\
Kinerja Pegawai $(\mathrm{Z})$ & .986 & 10 \\
\hline
\end{tabular}

Hasil pengujian reliabilitas pada Tabel di atas menunjukkan bahwa nilai koefisien Cronbach's Alpha dari variabel-variabel yang diteliti menunjukkan hasil yang beragam dan variabel menghasilkan nilai Cronbach's Alpha lebih besar dari 0,60. Dengan demikian dapat disimpulkan bahwa alat ukur yang digunakan dalam penelitian ini adalah reliabel.

c. Analisis Data Penelitian

\section{1). Pengujian Model Dengan Analisis Jalur (Path Analysis)}

Langkah perhitungannya adalah menghitung pengaruh langsung dan tidak langsung serta pengaruh total variabel bebas terhadap variabel terikat melalui variabel perantara kemudian menghitung residual variable (\&) atau variabel sisa yaitu variabel selain variabel bebas dan variabel perantara yang juga mempengaruhi variabel tergantung tetapi tidak dimasukkan dalam model penelitian. Rumus error adalah sebagai berikut (Imam ghozali; 2006): $\boldsymbol{\varepsilon}=\sqrt{\mathbf{1}-\boldsymbol{R}^{\mathbf{2}}}$

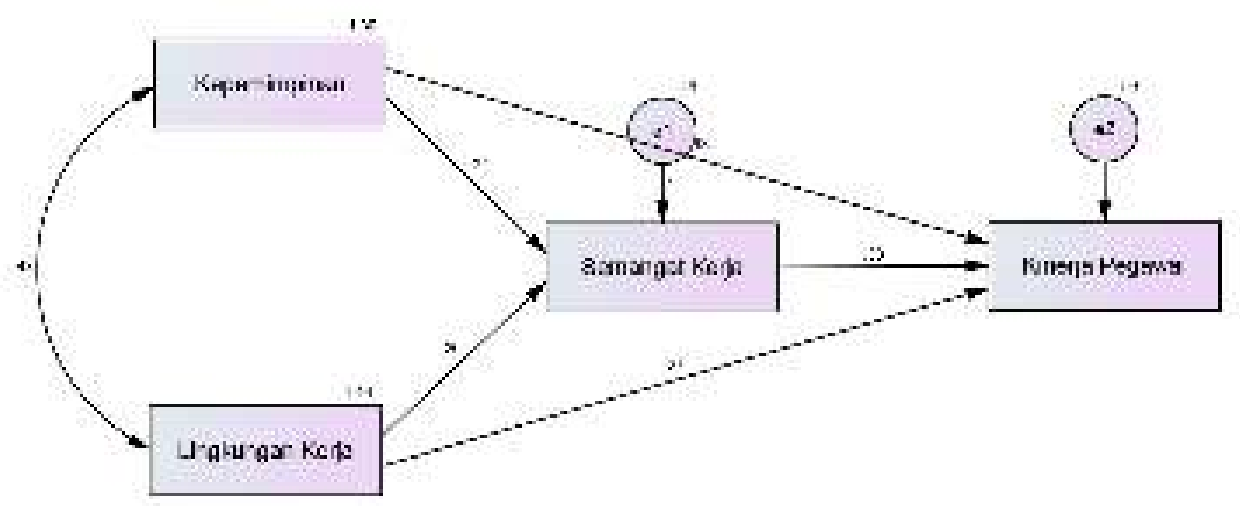

Gambar 2. Hasil Analisis Jalur

Bentuk persamaan standar dalam penelitian ini diperoleh sebagai berikut:

$$
\begin{array}{ll}
Y=\beta Y X_{1}+\beta Y X_{2}+\varepsilon & \text { (persamaan substruktur 1) } \\
Z=\beta Z X_{1}+\beta Z X_{2}+\beta Z Y+\varepsilon & \text { (persamaan substruktur 2) }
\end{array}
$$

Tabel 7. Hasil Estimasi Dengan Metode Path Analysis

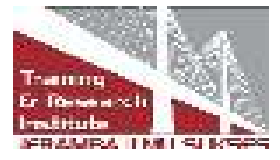


Regression Weights: (Group number 1 - Default model)

\begin{tabular}{lll|r|rrrr}
\hline & & & \multicolumn{1}{c}{ Estimate } & S.E. & C.R. & P & Label \\
\hline Rerata_Y & $<---$ & Rerata_X1 & $\mathbf{. 2 3 8}$ & $\mathbf{. 0 7 4}$ & $\mathbf{3 . 1 9 2}$ & $\mathbf{. 0 0 1}$ & par_1 \\
Rerata_Y & $<---$ & Rerata_X2 & $\mathbf{. 2 6 0}$ & $\mathbf{. 0 7 0}$ & $\mathbf{3 . 7 1 1}$ & $* * *$ & par_2 \\
Rerata.Z & $<---$ & Rerata_Y & $\mathbf{. 3 7 7}$ & $\mathbf{. 1 2 7}$ & $\mathbf{2 . 9 6 6}$ & $\mathbf{. 0 0 3}$ & par_3 \\
Rerata.Z & $<---$ & Rerata_X1 & $\mathbf{. 1 8 3}$ & $\mathbf{. 0 8 8}$ & $\mathbf{2 . 0 8 7}$ & $\mathbf{. 0 3 7}$ & par_4 \\
Rerata.Z & $<---$ & Rerata_X2 &. $\mathbf{2 6 9}$ & $\mathbf{. 0 8 4}$ & $\mathbf{3 . 1 8 8}$ & $\mathbf{. 0 0 1}$ & par_5 \\
\hline
\end{tabular}

2). Pengaruh Langsung (direct effect)

a). Pengaruh Kepemimpinan terhadap Semangat Kerja Pegawai

$$
\mathrm{X} 1 \rightarrow \mathrm{Y}=0,238
$$

Hasil diatas menunjukkan bahwa variabel Kepemimpinan berpengaruh terhadap variabel Semangat Kerja Pegawai sebesar 0,238.

b). Pengaruh Lingkungan Kerja Pegawai terhadap Semangat Kerja Pegawai

$$
\mathrm{X} 2 \rightarrow \mathrm{Y}=0,260
$$

Hasil diatas menunjukkan bahwa variabel Lingkungan Kerja Pegawai berpengaruh terhadap variabel Semangat Kerja Pegawai sebesar 0,260.

c). Pengaruh Kepemimpinan terhadap Kinerja Pegawai

$$
\mathrm{X} 1 \rightarrow \mathrm{Z}=0,183
$$

Pernyataan diatas menunjukkan bahwa variabel Kepemimpinan berpengaruh terhadap variabel Kinerja Pegawai sebesar 0,183.

d). Pengaruh Lingkungan Kerja Pegawai terhadap Kinerja Pegawai

$$
\mathrm{X} 2 \rightarrow \mathrm{Z}=0,269
$$

Hasil diatas menunjukkan bahwa variabel Lingkungan Kerja berpengaruh terhadap variabel Kinerja Pegawai sebesar 0,269.

e). Pengaruh Semangat Kerja Pegawai terhadap Kinerja Pegawai

$$
\mathrm{Y} \rightarrow \mathrm{Z}=0,377 \text {. }
$$

Hasil di atas menunjukkan bahwa variabel Semangat Kerja Pegawai berpengaruh terhadap variabel Kinerja Pegawai sebesar 0,377.

3). Pengaruh Tidak Langsung (indirect effect)

a). Pengaruh Kepemimpinan terhadap Kinerja Pegawai melalui Semangat Kerja Pegawai

$$
\mathrm{X} 1 \rightarrow \mathrm{Y} \rightarrow \mathrm{Z}=(0,238) .(0,377)=0,089726
$$

Hasil estimasi diperoleh bahwa nilai variabel Kepemimpinan sebesar 0,238 dan nilai koefisien variabel perantara Semangat Kerja Pegawai sebesar 0,377 menghasilkan nilai variabel Kinerja Pegawai sebesar 0,089726.

b). Pengaruh Lingkungan Kerja Pegawai terhadap Kinerja Pegawai melalui Semangat Kerja Pegawai

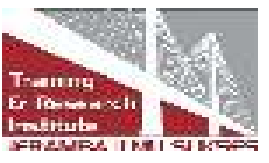




$$
\mathrm{X} 2 \rightarrow \mathrm{Y} \rightarrow \mathrm{Z}=(0,260) \cdot(0,377)=0,09802
$$

Berdasarkan hasil dari estimasi dapat diperoleh bahwa nilai variabel Lingkungan Kerja Pegawai sebesar 0,260 dengan nilai koefisien pada variabel perantara Semangat Kerja Pegawai sebesar 0,377 sehingga menghasilkan nilai variabel Kinerja Pegawai sebesar 0,09802.

4). Pengaruh Total (Total effect)

a). Pengaruh Kepemimpinan terhadap Kinerja Pegawai

Pengaruh Total $=$ Pengaruh langsung + Pengaruh Tidak Langsung

$$
\mathrm{TE}=0,183+0,089726=0,272726 .
$$

Berdasarkan pernyataan diatas dapat diperoleh bahwa variabel Kepemimpinan berpengaruh terhadap Kinerja Pegawai dengan nilai total yang diperoleh sebesar 0,272726.

b). Pengaruh Lingkungan Kerja Pegawai terhadap Kinerja Pegawai

Pengaruh Total $=$ Pengaruh langsung + Pengaruh Tidak Langsung

$$
\mathrm{TE}=0,269+0,09802=0,36702
$$

Berdasarkan pernyataan diatas dapat diperoleh bahwa variabel Lingkungan Kerja Pegawai berpengaruh terhadap Kinerja Pegawai dengan nilai total yang diperoleh sebesar 0,36702.

Berdasarkan perhitungan pengaruh antar jalur diketahui bahwa pengaruh langsung Kepemimpinan terhadap Kinerja Pegawai yaitu sebesar 0,183, sedangkan pengaruh tidak langsung Kepemimpinan terhadap Kinerja Pegawai yaitu sebesar 0,089726. Sedangkan untuk pengaruh langsung Lingkungan Kerja Pegawai terhadap Kinerja Pegawai yaitu sebesar 0,269, sedangkan pengaruh tidak langsung Lingkungan Kerja Pegawai terhadap Kinerja Pegawai yaitu sebesar 0,09802. Dengan demikian dapat disimpulkan bahwa jalur yang lebih efektif adalah jalur antara Kepemimpinan terhadap Kinerja Pegawai melalui Semangat Kerja Pegawai.

d. Uji Koefiien Determinasi $\left(\mathrm{R}^{2}\right)$.

Koefisien Determinasi digunakan dalam kaitannya dengan penggunaan analisis kolerasi untuk melihat besar kecilnya besaran kontribusi atas variabel bebas menjelaskan variabel terikat. Koefisien determinasi disebut juga koefisien penentu, karena varian yang terjadi pada variabel dependen dapat dijelaskan melalui variabel independen.

Dari hasil estimasi data rekap jawaban responden, maka hasil Koefisien Determinasi dapat dijelaskan melalui tabel berikut ini :

Tabel 8. Hasil Uji Koefisien Determinasi

Squared Multiple Correlations:

(Group number 1 - Default model)

\begin{tabular}{lc}
\hline & Estimate \\
\hline Semangat Kerja & $\mathbf{. 3 2 4}$ \\
Kinerja Pegawai & $\mathbf{. 4 3 6}$ \\
\hline
\end{tabular}

Hasil estimasi untuk pengaruh variabel Kepemimpinan $\left(\mathrm{X}_{1}\right)$, Lingkungan Kerja $\left(\mathrm{X}_{2}\right)$ mampu menjelaskan Variabel Semangat Kerja Pegawai sebesar 0,324 atau 32,4\%, sedangkan sisanya 
sebesar 67,6\% (100\% - 32,4\%) dijelaskan oleh faktor lain yang tidak diteliti. Menurut Nawawi (2018), faktor-faktor yang mempengaruhi tinggi rendahnya semangat kerja adalah: 1). Minat seseorang terhadap pekerjaan yang dilakukan. 2). Faktor gaji atau upah tinggi akan meningkatkan semangat kerja seseorang. 3). Status sosial pekerjaan. 4). Suasana kerja dan hubungan dalam pekerjaan. 5). Tujuan pekerjaan. Tujuan yang mulia dapat mendorong semangat kerja seseorang

Sedangkan untuk pengaruh variabel Kepemimpinan $\left(\mathrm{X}_{1}\right)$, Lingkungan Kerja $\left(\mathrm{X}_{2}\right)$ melalui Variabel Semangat Kerja mampu menjelaskan Variabel Kinerja Pegawai sebesar 0,436 atau $43,6 \%$, sedangkan sisanya sebesar 56,4\% dijelaskan oleh faktor lain yang tidak diteliti. Menurut Sutrisno (2010), faktor - faktor yang mempengaruhi kinerja karyawan 1). Efektivitas dan Efesiensi, 2). Otoritas dan Tanggung Jawab, 3). Disiplin dan 4). Inisiatif

\section{e. Perhitungan metode Path Analysis}

Dari hasil estimasi dengan menggunakan menggunakan metode Path Analysis, maka diperoleh nilai uji hipotesis secara parsial dalam tabel berikut ini :

Tabel 9. Hasil Estimasi Dengan Metode Path Analysis

Regression Weights: (Group number 1 - Default model)

\begin{tabular}{|c|c|c|c|c|c|c|c|}
\hline & & & Estimate & S.E. & C.R. & $P$ & Label \\
\hline Rerata Y & $<---$ & Rerata X1 & .238 & .074 & 3.192 & .001 & par 1 \\
\hline Rerata_Y & $<--$ & Rerata_X2 & .260 & .070 & 3.711 & $* * *$ & par_2 \\
\hline Rerata.Z & $<--$ & Rerata_Y & .377 & .127 & 2.966 & .003 & par 3 \\
\hline Rerata.Z & $<---$ & Rerata_X1 & .183 & .088 & 2.087 & .037 & par 4 \\
\hline Rerata.Z & $<---$ & Rerata_X2 & .269 & .084 & 3.188 & .001 & par 5 \\
\hline
\end{tabular}

Dalam metode estimasi dengan menggunakan metode Path Analysis, nilai Critical (CR) adalah sama dengan nilai $\mathrm{t}$ ( $\mathrm{t}_{\text {hitung }}$ ) pada regresi OLS dan $\mathrm{P}$ adalah tingkat probabilitas signifikansi dengan $* * *$ berarti signifikan pada $0,01(1 \%)$, tetapi untuk tingkat signifikansi $0,05(5 \%)$ nilai $\mathrm{P}$ (probabilitas signifikansi) tetap akan tampil pada tabel estimasi. Dari tabel probability t, maka diperoleh nilai $t_{\text {tabel }}=1,9798$, nilai ini akan dibandingkan dengan nilai CR pada tabel estimasi untuk menguji hipotesis secara parsial.

\subsection{Pembahasan}

a. Pengujian hipotesis pertama, Nilai $C R$-value dari variabel Kepemimpinan $\left(\mathrm{X}_{1}\right)$ sebesar 3,192 $>1,96$, sedangkan nilai $\mathrm{P}(P$-value $)=0,001$ nilainya berada dibawah $5 \%$ atau 0,05 maka Ha diterima. Hal ini berarti terdapat pengaruh antara Kepemimpinan $\left(\mathrm{X}_{1}\right)$ terhadap Semangat Kerja Pegawai (Y) pada Pegawai Dinas Sosial Kota Palembang.

b. Pengujian hipotesis kedua, Nilai $C R$-value dari variabel Lingkungan Kerja $\left(\mathrm{X}_{2}\right)$ sebesar 3,711 $>1,96$, sedangkan nilai $\mathrm{P}(P$-value $)=0,000$ nilainya berada dibawah $5 \%$ atau 0,05 maka Ha diterima. Hal ini berarti terdapat pengaruh antara Lingkungan Kerja $\left(\mathrm{X}_{2}\right)$ terhadap Semangat Kerja Pegawai (Y) pada Pegawai Dinas Sosial Kota Palembang.

c. Pengujian hipotesis ketiga, Nilai $C R$-value dari variabel Kepemimpinan $\left(\mathrm{X}_{1}\right)$ sebesar 2,087 $>1,96$, sedangkan nilai $\mathrm{P}(P$-value $)=0,037$ nilainya berada dibawah $5 \%$ atau 0,05 maka $\mathrm{Ha}$ diterima. Hal ini berarti terdapat pengaruh antara Kepemimpinan $\left(\mathrm{X}_{1}\right)$ terhadap Kinerja Pegawai (Z) pada Pegawai Dinas Sosial Kota Palembang.

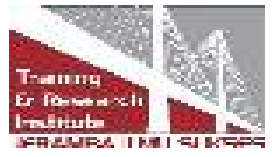


d. Pengujian hipotesis keempat. Nilai $C R$-value dari variabel Lingkungan Kerja $\left(\mathrm{X}_{2}\right)$ sebesar $3,188>1,96$, sedangkan nilai $\mathrm{P}(P$-value $)=0,004$ nilainya berada dibawah $5 \%$ atau 0,05 maka Ha diterima. Hal ini berarti terdapat pengaruh antara Lingkungan Kerja $\left(\mathrm{X}_{2}\right)$ terhadap Kinerja Pegawai (Z) pada Pegawai Dinas Sosial Kota Palembang.

e. Pengujian hipotesis kelima, Nilai $C R$-value dari variabel Semangat Kerja (Y) sebesar 2,966 $>1,96$, sedangkan nilai $\mathrm{P}(P$-value $)=0,003$ nilainya berada dibawah $5 \%$ atau 0,05 maka Ha diterima. Hal ini berarti terdapat pengaruh antara Semangat Kerja $\left(\mathrm{Y}_{1}\right)$ terhadap Kinerja Pegawai (Z) pada Pegawai Dinas Sosial Kota Palembang.

f. Pengujian hipotesis keenam, Hasil estimasi diperoleh bahwa nilai variabel Kepemimpinan sebesar 0,238 dan nilai koefisien variabel perantara Semangat Kerja Pegawai sebesar 0,377 menghasilkan nilai variabel Kinerja Pegawai sebesar 0,089726 pada Pegawai Dinas Sosial Kota Palembang.

g. Pengujian hipotesis ketujuh, berdasarkan hasil dari estimasi dapat diperoleh bahwa nilai variabel Lingkungan Kerja Pegawai sebesar 0,260 dengan nilai koefisien pada variabel perantara Semangat Kerja Pegawai sebesar 0,377 sehingga menghasilkan nilai variabel Kinerja Pegawai sebesar 0,09802 pada Pegawai Dinas Sosial Kota Palembang.

\section{Kesimpulan}

Hasil dan pembahasan menyimpulkan pertama, Kepemimpinan berpengaruh signifikan terhadap semangat kerja Pegawai. Kedua, Lingkungan Kerja, berpengaruh signifikan terhadap semangat kerja Pegawai. Ketiga,Kepemimpinan berpengaruh signifikan terhadap kinerja Pegawai. Keempat, Lingkungan Kerja berpengaruh signifikan terhadap kinerja Pegawai. Kelima, Semangat Kerja berpengaruh signifikan terhadap kinerja Pegawai. Keenam, Kepemimpinan melalui Semangat Kerja berpengaruh signifikan terhadap kinerja Pegawai. Ketujuh, Lingkungan melalui Semangat Kerja berpengaruh signifikan terhadap kinerja Pegawai Dinas Sosial Kota Palembang. Saran sebagai rekomendasi yang berguna bagi Dinas Sosial Kota Palembang, pertama, Semangat Kerja Pegawai mempunyai kontribusi terbesar terhadap Kinerja Pegawai. Semangat Kerja dan Lingkungan Kerja Pegawai juga perlu dipertahankan yang berdampak pada Kinerja Pegawai. Namun Lingkungan Kerja juga perlu ditingkatkan. Kedua, Lingkungan Kerja Pegawai perlu ditingkatkan agar Semangat Kerja Pegawai meningkat,sehingga kinerja pegawai juga meningkat. Ketiga, Kepemimpinan terhadap Semangat Kerja Pegawai, masih bernilai rendah. Pimpinan seharusnya memberikan contoh yang baik pada pegawainya. Keempat, Kepemimpinan terhadap Kinerja Pegawai perlu ditingkatkan, karena Kepemimpinan berpengaruh terhadap Kinerja Pegawai. Kepemimpinan melalui Semangat Kerja. Kelima, perlu adanya pengawasan dan evaluasi dari pimpinan. Begitupun Lingkungan Kerja melalui Semangat Kerja pada Pegawai Dinas Sosial Kota Palembang perlu ditingkatkan. berpengaruh signifikan terhadap variabel Kinerja Pegawai. Sehingga perlu pengawasan dan evaluasi pada Pegawai Dinas Sosial Kota Palembang.

\section{Referensi}

Aziizah, Rachmawati Deasy. (2018). "Pengaruh Gaya Kepemimpinan Kepala Sekolah Dan Motivasi Kerja Guru Terhadap Kinerja Guru di SMA PPMI Assalam Surakarta.” Industrial Engineering Journal 7(2):18-24.

Berdi, B. (2019). Pengaruh Motivasi Dan Kompensasi Terhadap Prestasi Kerja Guru Sma St. Carolus. Jurnal Mitra Manajemen (JMM Online). 
Dayanti, Wulan Ria. (2014). "Pengaruh Komunikasi Interpersonal, Ketelitian (Conscientiousness) dan Kepuasan Kerja Terhadap Kinerja Kepala Sekolah PAUD di Medan Deli.” Jurnal Pendidikan Dan Kepengawasan, Vol 2 No. 2 Oktober 2014 2(2):33-49.

Desi SR, Nasir A, Sofyan I. (2018). Pengaruh Kompetensi, Gaya Kepemimpinan, Budaya Kerja dan Lingkungan Kerja terhadap Kepuasan Kerja Pegawai dan Dampaknya Terhadap Kinerja Pegawai Kantor Kementerian Agama Kabupaten Aceh Barat. Jurnal Magister Manajemen FEBisnis Unsyiah. Volume 2, No. 1, Januari 2018. Banda Aceh.

Emron et al. (2016). Manajemen Sumber Daya Manusia. Bandung: Alfabeta.

Fahmi, Irham. (2016). Perilaku Organisasi. Alfabeta, Bandung.

Ferdinand, Augusty. (2014). Metode Penalitian Manajemen. Universitas Diponegoro

Firmansyah, AH. (2018). Pengaruh Gaya Kepemimpinan Situasional Dan Kompensasi Terhadap Kepuasan Kerja Melalui Kinerja SMA Internasional Budi Mulia 2 Yoyakarta. Jurnal Manajerial Bisnis.

Flippo, Edwin B. (1988). Manajemen Personalia. Edisi Ke-enam Jilid I. (Alih Bahasa oleh Mohamad Masud. Jakarta: Erlangga

Ghozali, Imam. (2013). Aplikasi Analisis Multivariate dengan Program IBM SPSS.Semarang: Badan Penerbit Universitas Diponegoro.

Goyena, Rodrigo. (2019). “Kepuasan Kerja \& Kinerja.” Journal of Chemical Information and Modeling 53(9):1689-99.

Hasibuan, Malayu S.P. (2005). Manajemen Sumber Daya Manusia. Jakarta: Bumi Aksara

Luthans, Fred. (2011). Organizational Behavior : An Evidence-Based Approach. New York: McGraw-Hill.

Luthans, Fred. (2006). Perilaku Organisasi. Edisi Ke - 10. Andi. Yogjakarta.

Martinus, Patahuddin, Syahrul. (2019). Pengaruh Tunjangan Profesi dan Kepuasan Kerja Terhadap Kinerja Guru SMP Negeri di Kecamatan Biringkanaya. Penelitian dan Evaluasi Pendidikan. Program Pascasarjana Universitas Negeri Makassar

Maulana, Muhammad Kausar. (2019). "Pengaruh Penempatan Dan Lingkungan Kerja Terhadap Prestasi Kerja Karyawan Pt. Jelajah Laut Nusantara Jakarta.” Jurnal Ekonomi Dan Industri 20(1).

Miner, John. (1998). Organizational Behavior, Performance and Productivity. New.

Oktavianti, R., Soedjarwo, \& Basuki, I., Analisis Pengaruh Pemberian Kompensasi Non Finansial Terhadap Komitmen Dan Kinerja Guru SMA Se Kota Semarang. Pascasarjana Manajemen Pendidikan, Universitas Negeri Surabaya.

Purnama, I., Nyoto, Komara AH. (2019). Pengaruh Gaya Kepemimpinan, Motivasi Kerja, Dan Lingkungan Kerja Terhadap Kepuasan Kerja Guru Dan Komitmen Organisasi Guru Di SMA Negeri Kota Amlapura.

Putra, BW. (2019). Pengaruh Kompensasi Dan Motivasi Terhadap Kepuasan Kerja Guru SMA Negeri Jakarta Utara. Jurnal Ekonomi dan Industri Volume 20, No.2, Mei-Agustus. 
Rahma, M. (2019). Pengaruh Lingkungan Kerja, Diklat, Dan Pengembangan Karir Terhadap Kepuasan Kerja Implikasinya Terhadap Kinerja Guru di SMPN kota Semarang. Mahasiswa Magister Manajemen Fakultas Ekonomi dan Bisnis UNIKI.

Rizki Kurniawan. (2019). Pengaruh Kepemimpinan, Motivasi, Lingkungan Kerja dan Budaya Organisasi Terhadap Kinerja yang Berdampak pada Prestasi Kerja. JEM: Jurnal Ekonomi dan Manajemen STIE Pertiba Pangkalpinang. Vol 5, No. 1, Edisi Juli 2019, hal 115-134

Robbins, Stephen P. \& A. Judge, Timothy (2011). Organizational behavior. Fourteenth Edition. Pearson education. New Jersey 07458. 77-89*.

Sedamaryanti. (2003). Sumber Daya Manusia dan Produktivitas Kerja, Yogyakarta:Mandar Maju

Sholihin, Moh. (2019). “Analisis Pengaruh Kepemimpinan, Budaya Organisasi Dan Kompensasi Terhadap Kinerja Karyawan AMA YPK Yogyakarta Dengan Motivasi Kerja Sebagai Variabel Intervening." Albama 9(2):95-134.

Sutrisno, Edi. (2014). Manajemen Sumber Daya Manusia Jakarta: Kencana Prenada Media Group

Veithzal Rivai et al. (2008). Performance Appraisal. Jakarta: PT. Raja Grafindo Persada.

\section{Copyrights}

Copyright for this article is retained by the author(s), with first publication rights granted to the journal.

This is an open-access article distributed under the terms and conditions of the Creative Commons Attribution license (http://creativecommons.org/licenses/by/4.0/) 